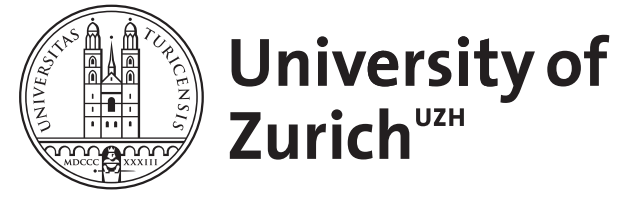

\title{
Why invest in art?
}

Frey, Bruno S ; Cueni, Reto

\begin{abstract}
In recent years, the art market experienced a price explosion for paintings. Frey and Cueni shed light on the reasons for the price increase, on the rate of return in the art market, on the emergence and decline of art hedge funds, and on the risks of art investments
\end{abstract}

DOI: https://doi.org/10.1515/ev-2013-0014

Posted at the Zurich Open Repository and Archive, University of Zurich ZORA URL: https://doi.org/10.5167/uzh-154941

Journal Article

Published Version

Originally published at:

Frey, Bruno S; Cueni, Reto (2013). Why invest in art? The economists' voice, 10(1):1-6.

DOI: https://doi.org/10.1515/ev-2013-0014 


\section{Bruno S. Frey* and Reto Cueni Why Invest In Art?}

Abstract: In recent years, the art market experienced a price explosion for paintings. Frey and Cueni shed light on the reasons for the price increase, on the rate of return in the art market, on the emergence and decline of art hedge funds, and on the risks of art investments.

Keywords: art market; hedge funds; investment; psychic return; risk.

\footnotetext{
*Corresponding author: Bruno S. Frey, Zeppelin University, Germany; and CREMA-Center for Research in Economics, Management and the Arts, Switzerland, e-mail: bruno.frey@econ.uzh.ch
}

Reto Cueni: University of Zurich, Switzerland

\section{Introduction}

The record prices paid for paintings at auctions frequently attract the media's attention. In 2012, Edvard Munch’s “The Scream” was sold for \$120 million. That same year, Souren Melikian published an article in the New York Times complaining about the gradual transformations of the art market. He stated that decades ago, connoisseurs had been relying on their eyes when buying art; these days, according to Melikian, investors are driving the market without any sense for the beauty of art, only relying on the advice of art consultants and auction houses. If not because of its beauty, why do these people rush into the art market?

Status cannot fully account for the paradoxical price increase during the last recession. The strive for status is at least as old as art itself. Articles in the Wall Street Journal, Reuters or Forbes, among others, point out that there might be a third force at work: Art investment funds. For these funds, status is definitively not the relevant criterion for investment decisions. They buy and sell artworks anonymously. Investment funds deal with art because they want to make profits. But do they really make profits? And if not, what are the hidden costs and risks of art investments? In this essay, we analyze these questions and provide possible explanations.

\section{Is Art Investment Profitable?}

Considering the high prices paid at art auctions in recent years, the answer seems to be obvious. However, over a longer time period, the high prices are only partly 
reflected in high rates of return on investment in art. In an article published in Management Science this year, Renneboog and Spaenjers show that, for example, in 1987 the real rate of return on art investment was no $<37$ percent per year (p.a.), and in 2007 it exceeded 22 percent p.a. However, over the period 1957-2007, the real rate of return was only 3.9 percent p.a. In some years, it was even highly negative, as in 1991 where it reached -32 percent p.a.

Artworks are taken to be unique and, hence, no substitutes exist to compare prices of artworks of the same quality. Moreover, most artworks are only rarely traded.

There exist two methods to calculate the rate of return on art objects:

- Repeat sales regressions. They estimate the returns based on the purchase and sales price of the identical art object traded several times. Repeat sales regressions allow controlling for art quality, but the data are of limited extent and disregard the many art objects that are only sold once; hence, selection bias plays an important role.

- Hedonic regressions. This method takes into account all auction results. A regression is then used to identify the hedonistic factors affecting price (e.g., artistic reputation, authenticity, size, topic, date of origin), including time dummies to measure positive or negative returns. It is assumed that the timeinvariant quality is captured by the hedonic characteristics. Yet, if this is not the case, the estimates are biased due to omitted variables.

Despite these difficulties, the work of art economists has produced valuable insights on the rates of return on art markets. William Baumol's seminal study in 1986 points out that, when considering all the additional risks and frictions on the art market, investment returns in art do not exceed their opportunity costs. Frey and Eichenberger provide an extended survey of studies on art market returns covering the period from 1977 until 1995. Again, the general picture is that investment in art on average yields a lower rate of return than financial investments. The recent study by Renneboog and Spaenjers includes more than one million auction trades for 10,000 artists over the period 1900-2007. Using a hedonic regression, they calculate a geometric mean real return, as well as the dispersion and the Sharpe ratio for investments in art. The authors compare these numbers to equities, bonds and gold, as shown in Table 1.

While stocks yield a return of over 6.5 percent, for art it is only 4 percent per year. However, art investment is shown to be more profitable than government bonds and gold, which yield returns between 2 percent and 3 percent p.a. Compared to corporate bonds, the average return on art is the same, whereas the risk in terms of price variations is about 10 percent points higher for art investments than for corporate bonds. Compared to gold, art delivers a higher return at a much 
Table 1 Comparison of real returns on investment (period 1995-2007).

\begin{tabular}{lrrr}
\hline & Mean & Dispersion (S.D.) & Sharpe Ratio \\
\hline Art & $4.0 \%$ & $19.0 \%$ & 0.200 \\
Equities & $6.6 \%$ & $16.5 \%$ & 0.411 \\
Corporate Bonds & $4.0 \%$ & $9.5 \%$ & 0.344 \\
Government Bonds & $2.7 \%$ & $10.6 \%$ & 0.185 \\
Gold & $2.3 \%$ & $24.2 \%$ & 0.128 \\
\hline
\end{tabular}

Source: Renneboog and Spaenjers (forthcoming). Table 1 displays the geometric mean real returns on art, equities (measured by the Standard \& Poor's 500 Index), government bonds (10-year U.S. government bonds), corporate bonds (Dow Jones corporate bonds), and gold (Gold Financial Data world index for gold prices). The second column shows the distribution of the returns measured by the standard deviation of the corresponding distribution. The last column displays the Sharpe Ratio of the corresponding asset class, calculated as the arithmetic average excess return divided by its standard deviation.

lower risk, which is indicated by the lower Sharpe ratio of gold. Although the investment performance of art is not overwhelming, the figures reveal another reason to invest in art: hedging.

In a period of financial turmoil, many investors seek to place their money in a comparatively safe asset class. In 2009, Jeff Segal and Jeffrey Goldfarb reported that hedge funds tried to offer protection against inflation to investors by investing in art. According to Renneboog and Spaenjers, art investment can serve as a hedging instrument against inflation and as a possibility to diversify a portfolio. They provide evidence that art is not correlated with financial assets such as equities or bonds, but that it is associated with tangible assets such as gold or commodities. In an earlier study, Dimson and Spaenjers claim that art can serve at least partially as a good hedging instrument against inflationary risks - only gold is more immune to inflation. Despite these findings, Adam Davidson reported last year in a New York Times article that many of the art hedge funds have collapsed. How can this happen?

\section{Art Investment Risks}

Investment in art is part of what is called "alternative investment," i.e., investment other than stocks, bonds or cash. Such investment has some typical characteristics: The current market value is difficult to evaluate; compared to financial assets such objects are more illiquid; the information needed before investing is substantial; and the cost of purchase and sale may be high. 
The art market shares these characteristics. Almost half of all transactions have been judged to occur at auctions, the other half are handled by art dealers. Auction prices nevertheless dominate the market as they serve as guidelines to art dealers. While transaction costs on financial markets typically are below 1 percent of the price, in auctions the seller and buyer have to pay a commission between 10 percent and 25 percent of the hammer price. These costs are often disregarded when estimating returns on art investments. Dimson and Spaenjers are an exemption: When considering transaction costs at sale of 25 percent, the investments in expensive British stamps, as a sort of art investment, have to have a holding period of at least 4 years to reach a positive return after costs, compared to equity with $<3$ month on average. In almost all studies on the art market, the estimated return has to be considered an upper bound prior to transaction costs. Transaction costs are, however, crucial when considering art investments. It is an open question whether the market forces exerted by web-auction houses such as artnet.com, artprice.com or eBay-Art can sustainably reduce transaction costs. Generally, these web auction houses offer better access for sellers and buyers to auctions as well as lower transaction costs. They range between 5 percent and 10 percent of the price fetched, depending on the level of prices and the amount of lots sold.

In addition to transaction costs, buyers of art objects are confronted with special risks beyond price variability. The first set of risks refers to the art object itself. The buyer can never be certain whether the object acquired is an original or whether it is a copy or an outright forgery. This is not always a problem. In Asian art, as well as with orthodox icons, copying is commendable, as it expresses honoring the past. Nevertheless, in Western art primarily sold at auctions today, authenticity is an important feature.

Similarly, attribution has a strong influence on prices of art. Whether a painting was made by the master himself, the circle, the school, or whether it is only in the style of a grand master is crucially important. Frey and Pommerehne report the story of the painting “Daniel in the Lion's Den”. In 1882, the work was sold at Christie’s London for $€ 1680$. After the attribution of the painting was changed to Jakob Jordaens, it was sold in 1963 for only £500. Two years later, the New York Metropolitan Museum bought the painting for $£ 178,600$ after the work was attributed to Rubens again.

Another specific feature of art objects is their quality. Over the centuries, many paintings have suffered and have been repainted. Such manipulations tend to reduce the prices paid. The risks just mentioned are substantial in the arts market but nearly absent in the financial market these days.

In addition, the buyers of art run the risk that the object in their possession could be stolen or may be destroyed by fire, in wars and revolutions, or may be 
the target of terrorist attacks. To guard against at least some of these risks the art object may be insured but the premium to be paid is substantial and lies between 0.1 percent and 0.5 percent of the artwork's value.

The second set of risks of special importance in the art market refers to unforeseen public interventions. Governments may simply seize art objects claiming that they are part of "national heritage." They may change the sales or property tax or change the property rights away from the owner towards the artist who created the art object. Governments may also impose new export restrictions.

A third set of risks is shared with other investment but may affect the art market more strongly than financial markets. William Goetzmann, Luc Renneboog and Christophe Spaenjers present evidence that a 1 percent fall in income of the earners in the top 0.1 percent income distribution in the UK triggers a fall in art prices of almost 10 percent.

A fourth set of risks refers to the unpredictable changes in tastes and fashions prevalent in the art world. Art markets are characterized by extreme heterogeneity. Perceptions play an even more important role than on financial markets, as they reflect purely personal preferences.

A final set of risks is due to the important role behavioral anomalies are likely to play in the arts. There is certainly a stronger ownership bias than is the case with financial instruments: once a collector owns a piece of art, he or she establishes a special relationship to it and tends to be unwilling to sell it. Collectors also tend to buy art produced by domestic artists. This home bias seems to be larger than the equity home bias in financial markets. There might also be more pronounced herding behavior on the buyers' side than on financial markets because, as William Baumol notes in his seminal article, art objects do not have any "natural" value, which could be used as a reference point for their valuation.

\section{To Invest or Not to Invest in Art?}

Investments in financial assets normally yield only a monetary return while the possession of art in addition yields a psychic return due to the pleasure and social esteem of holding an artwork. In a competitive market the overall rate of return is equalized. It follows that the financial return must be smaller than in other markets where no such psychic return exists. As an investor, it is impossible to reliably forecast the financial return on any market. In contrast, the psychic return as an art collector is much better predictable. This is an important incentive to engage in art investment. 


\section{References and Further Reading}

Baumol, William. 1986. “Unnatural Value: Or Art Investment as Floating Crap Game.” American Economic Review (Papers and Proceedings) 76 (2): 10-14.

Carolin Copley. 2012. “Art Basel Tests Buyers' Instincts in time of crisis.” June 13. http://www. reuters.com/article/2012/06/13/uk-arts-basel-idUSLNE85C01E20120613.

Davidson, Adam. 2012. “How the Art Market Thrives on Inequality.” The New York Times, May 30. http://www.nytimes.com/2012/06/03/magazine/how-the-art-market-thrives-oninequality.html.

Dimson, Elroy and Christophe Spaenjers. 2011. "Ex Post: The Investment Performance of Collectible Stamps.” Journal of Financial Economics 100: 443-458.

Frey, Bruno S. 2003. Arts \& Economics: Analysis \& Cultural Policy. Berlin, Heidelberg, New York: Springer.

Frey, Bruno S. and Werner Pommerehne. 1989. Muses and Markets: Explorations in the Economics of the Arts. Oxford: Basil Blackwell.

Frey, Bruno S. and Reiner Eichenberger. 1995. “On the Rate of Return in the Art Market: Survey and Evaluation.” European Economic Review 39 (3-4): 528-537.

Goetzmann, William, Luc Renneboog and Christophe Spaenjers. 2011. “Art and Money." American Economic Review (AEA Papers and Proceedings) 101: 222-226.

Melikian, Souren. 2012. "The Impoverished Connoisseurs." The New York Times, September 12. http://www.nytimes.com/2012/09/13/arts/13iht-rartmelikian13.html?_ $\mathrm{r}=1 \& \mathrm{ref}=$ sourenmelikian.

Renneboog, Luc and Christophe Spaenjers. 2013. "Buying Beauty: On Prices and Returns in the Art Market." Management Science 59 (1): 36-53.

Rogers, Joshua. 2012. “How to Outsmart the Billionaires Who'll Bid $\$ 80$ Million for The Scream.” April 4. http://www.forbes.com/sites/joshuarogers/2012/04/04/how-tooutsmart-the-billionaires-wholl-bid-80-million-for-the-scream/.

Segal, Jeff and Jeffrey Goldfarb. 2009. “Art Appreciated as Inflation Hedge.” The New York Times, May 12. http://www.nytimes.com/2009/05/12/business/12views.html .

The Wall Street Journal. 2009 “The Million-Dollar Penny.” November 19. http://online.wsj.com/ article/SB10001424052748703811604574533732182243424.html.

Bruno S. Frey is Professor of Economics at the Zeppelin University in Friedrichshafen (Germany). In addition, he is director of the Center for Research in Economics, Management and the Arts (CREMA), Basel, Switzerland. His research analyzes the economics of art and culture, the use of awards, and the economics of happiness.

Reto Cueni is a Doctoral Student and Lecturer at the University of Zurich, Switzerland. He focuses on empirical research on herding behavior in different markets, such as the art or the financial market. 